\title{
The Practice Of Giving Bonus To Wadi'ah Current Accounts At Bank Sharia In Palangka Raya From A Sharia Economic Perspective
}

\author{
Jamilah', Enriko Tedja Sukmana $^{\text {2, Muhammad Riza Hafizi }}{ }^{3}$, \\ Institut Agama Islam Negeri Palangka Raya \\ Jl. G.Obos Komplek Islamic Center, Palangka Raya, Kalimantan Tengah Email: \\ jamilaja05@gmail.com, riza.hafizi@iain-palangkaraya.ac.id
}

\begin{abstract}
Abstrak
Produk giro Bank Syariah Mandiri Cabang Palangka Raya mengunakan akad wadiah. BSM memberikan keuntungan berupa bonus setiap bulannya kepada nasabah giro sebagaimana yang tertera pada laman website BSM yaitu "bonus bulanan yang diberikan sesuai dengan kebijakan”. Penelitian ini bertujuan untuk mengetahui praktik pemberian bonus pada produk giro wadi'ah di BSM Cabang Palangka Raya ditinjau dalam perspektif ekonomi Islam. Penelitian ini merupakan penelitian lapangan dengan metode kualitatif. Hasil penelitian menunjukkan bahwa praktik pemberian bonus pada produk giro wadiah telah sesuai dengan perspektif ekonomi Islam. Pertama, bonus tidak diperjanjikan dalam akad, Bonus diberikan tergantung keuntungan yang diperoleh bank setiap bulannya disertai kebijakan. Kedua, pernyataan pemberian bonus melalui laman website BSM merupakan salah satu bentuk promosi yang dapat dibenarkan, hanya saja jika pemberian bonus menjadi bagian dari persyaratan yang dapat mengarahkan pada riba dan akan menjadi kelaziman karena terus menerus dilakukan, maka pemberian bonus tersebut dapat menjadi kesalahan yang perlu ditelaah ulang.
\end{abstract}

\section{Kata kunci: Bonus, Giro Wadi'ah, Bank Syariah, Ekonomi Islam}

\begin{abstract}
The wadi'ah yad dhamanah contract that is applied to current accounts at the Palangka Raya Branch of Bank Syariah Mandiri, is basically a wadi'ah contract, which theoretically does not allow the recipient of the deposit (bank) to declare the previous reward or benefit to the wadi'ah account holder (customer). BSM Palangka Raya Branch provides benefits in the form of bonus every month to current accounts as previously stated on the BSM website, namely "monthly bonus given in accordance with BSM policies". Bonus are given based on BSM policies. Second, the statement of giving bonus through the BSM website is a form of promotion can be justified, it's just that if bonus are part of the requirements that can lead to the practice of hidden usury and will become the norm because it is continuously being done, then giving this bonus can be a mistake which should be reviewed by BSM.
\end{abstract}

Keywords: Of Giving Bonus, Wadi'ah Current Account, Islamic Banks, Islamic Economic 
The Practice Of Giving Bonus To Wadi'ah Current Accounts

At Bank Sharia In Palangka Raya From A Sharia

Economic Perspective

Jamilah, dkk

\section{INTRODUCTION}

The conception of Islamic economics refers to sharia which is the rule of the Islamic religion, because every human action including economic and development policies, as well as community economic activities must be bound by sharia law. The development of Islamic banking is basically an integral part of the development of the Islamic economy. (Fitria, 2016: 39). Sharia banks are financial institutions that function to smoothen the economic mechanism in the real sector through investing or buying and selling activities, as well as providing savings / banking services for customers based on sharia principles. (Arifin, 2006: 2-3).

Islamic banks have their own techniques in collecting public funds, among which conventional bank products can be included, one of which is demand deposits. (Kasmir, $2002: 76-77$ ). In practice, the majority of current accounts in Islamic banking use contracts wadi'ah, because they are cheap funds, and banks do not promise profits. In addition, Islamic banks use these products because they have the appeal of checks as a means of payment, customers use current acounts wadi'ah in general because of their features that can be taken at any time, and this is their bargaining power and the market still needs them (Darsono \& Antonio, 2017: 89-90).

A wadi'ah contract is a pure deposit from one party to another, both individuals and legal entities that must be maintained and returned whenever the depositor wants (Hasan, 2014: 204). The pattern of contracts wadi'ah that is most widely applied is wadi'ah yad dhamanah, as well as those applied to syariah bank checking accounts because with this pattern, it makes it possible for Islamic banks to utilize the funds raised for productive activities. So that the pattern applied to Islamic banking demand deposits is wadi'ah yad dhamanah. (Darsono \& Antonio, 2017: 90).

Based on observations, the Palangka Raya branch of Bank Syariah Mandiri has current accounts with the contract wadi'ah yad dhamanah. In practice, customers act as depositors who give Bank Syariah Mandiri 
the right to use and utilize their deposited funds, while Bank Syariah Mandiri is the party entrusted with funds or deposited money. Bank Syariah Mandiri can use the deposited funds with the customer's permission to be channeled back in the form of financing that can generate profits. Bank Syariah Mandiri can provide these benefits to customers in the form of monthly bonus in accordance with Bank Syariah Mandiri policies. The Palangka Raya branch of Bank Syariah Mandiri itself has attracted 46 current account customers, most of whom use BSM Giro products (B.P.S. Customer Service, 21/10/19).

Through the page, it is website Bank Syariah Mandiri Explained that the advantages of BSM Giro deposit funds are safe and available at any time, transactions are easier using check / bilyet giro, and get monthly bonus that are given in accordance with Bank Syariah Mandiri policies (www.mandirisyariah.co.id.). In theory, the recipient of the deposit (bank) may not state rewards or benefits to the account holder wadi'ah (customer) (Widayatsari, 2013:7). Deposited products are not allowed in the form of promises about bonus in advance, either in writing or orally (Murdadi, 2015: 68).

Bank Syariah Mandiri Palangka Raya Branch provides rewards or benefits in the form of bonus every month to current account customers as previously stated on the website Bank Syariah Mandiri, namely "monthly bonus given in accordance with Bank Syariah Mandiri (A.S. Branch Operation \& Service Manager, 18/06/20). As previously explained, the contract wadi'ah yad dhamanah that is applied to current accounts at the Palangka Raya Branch of Bank Syariah Mandiri, is basically a contract wadi'ah (deposit) which in theory the recipient of the deposit (bank) may not declare a reward or profit in initial either in writing or orally to the account holder wadi'ah (customer).

Based on this, the researcher sees that there is a need for a more detailed explanation regarding the practice of giving bonus at the Palangka Raya branch of the Syariah Mandiri Bank whether it is in accordance with an Islamic economic perspective. So that later the public will be clearer 
and truly understand how the practice of giving bonus to current accounts at Bank Syariah Mandiri, Palangka Raya Branch.

\section{LITERATURE REVIEW}

Current accounts wadi'ah are public deposits which can be withdrawn at any time by means of checks, bilyet giro or other transfers. Meanwhile, the deposit can be made in cash. Clearing and book-entry. This product is a pure deposit using a contract wadi'ah which the bank may use with the permission of the depositor. This product does not have a profit sharing agreement because the contract used is not a business cooperation but a deposit, however the bank will provide a bonus based on the bank's discretion. The bank provides statements of bank statements, transfers and other transactions every month (Darsono \& Antonio, 2017 : 71). Bonus ('athayâ), which is a gift given by a bank to a customer who saves his funds in the bank in the form of a savings or current account wadí'ah. In general, bonus are immaterial (Mubarok, Hasanudin, \& Sanrego, 2016 : 341). The giving of bonus is practiced by Islamic Banks in accordance with the National Sharia Council Fatwa No: 01 / DSN-MUI / IV / 2000 concerning Current Accounts. According to the fatwa, a wadi'ah current account does not require a reward, except in the form of a gift voluntary ('athaya) from the bank. In addition, this form of demand deposit is also a deposit and can be collected at any time (on call) (Hakim, 2011: 209).

National Sharia Council Fatwa No.86 / DSN-MUIXII / 2012 concerning Prizes in raising funds for Islamic Financial Institutions, explains that it is permissible to give gifts /'athaya for customer deposits, provided that: First, Not agreed as the substance of the DSN-MUI Fatwa No. ol / DSN-MUI / IV / 2000 concerning Current Acounts, and No. 02 / DSNMUI / IV / 2000 concerning Savings; Second, Does not lead to hidden usury practices; and / or ; Third, Not be customary (habit, 'urfy).

According to sharia economics and finance expert Suherman Rosyidi stated that $u r f$ ' or the prevalence prohibited by the MUI DSN in the prize fatwa aims to avoid changing one's intention from the intention to save or 
place funds to want to get a prize (Setiawan, Rahmawati, \& Wahidin, 2019 : 41). Sharia Financial Institutions give prizes to customers in order to attract the public to fund collection products in the form of promotional prizes and prizes for customer savings. Gifts (hadiyah) is a provision which is not binding, and intended to make customers loyal to the Islamic Financial Institutions (Fatwa Dewan Syariah Nasional No.86/DSNMUIXII/2012 Tentang Hadiah Dalam Penghimpunan Dana Lembaga Keuangan Syariah : 8).

Promotion is an activity to communicate and introduce products carried out by a company on its marketing targets. Technology and information enables Islamic banks to expand their marketing scope, in this case the technology and information is carried out via the internet. The tool used as an online marketing medium is internet marketing.generally Internet marketing consists of websites, social media, ads banner, online affiliates, sponsorships, search engine marketing and email. Through these various forms of internet marketing, customer satisfaction has always been the main focus in the Islamic banking industry in order to win the competition (Napitupulu, $2016: 180$ ).

\section{METHODS}

This research was conducted at Bank Syariah Mandiri Palangka Raya Branch Jl. Ahmad Yani No.75 Palangka Raya City. The time of research on the practice of giving bonus to giro products wadi'ah at the Palangka Raya branch of the Bank Syariah Mandiri was reviewed from an Islamic economic perspective for 3 months starting from March 12 to June 12, 2020 when the research permit issued by the State Islamic Institute ( IAIN) Palangka Raya. Subjects of this study were two staff of the Palangka Raya branch of Bank Syariah Mandiri, namely the Branch Operations \& Service Manager (BOSM) Syariah Mandiri Branch of Palangka Raya and Customer Service (CS) Syariah Mandiri Palangka Raya Branch. The informants in this study are two BSM Giro customers. The object of this research is the practice of giving bonus to current accounts wadi'ah at 
The Practice Of Giving Bonus To Wadi'ah Current Accounts

At Bank Sharia In Palangka Raya From A Sharia

Economic Perspective

Jamilah, dkk

Bank Syariah Mandiri Palangka Raya Branch. This research uses observation, interview and documentation techniques in collecting the data needed in conducting this research. To determine the level of data validation in this study, researchers used data triangulation. The triangulation used was source triangulation.

\section{DISCUSSION}

The Practice of giving bonus to current accounts at Bank Syariah Mandiri Palangka Raya Branch.

In practice, the majority of Islamic banking uses contracts wadi'ah, because it is cheap funds, and banks do not promise profit. The application of the contract is wadi'ah yad dhamanah mostly applied to current accounts in Islamic banks (Darsono \& Antonio, 2017: 89-90). This wadi'ah yad dhamanah contract is also applied at the Palangka Raya branch of the Syariah Mandiri Bank, namely its current account products.

Current accounts are one of the types of deposits owned by Bank Syariah Mandiri Palangka Raya Branch, current account products available include BSM Giro, BSM Giro Valas, BSM Giro Singapore, and BSM Giro Euro. The advantage of this current account product is, for customers who have a business with a large enough number of transactions, customers can deposit large amounts of funds in this current account product, making it easier for customers to make payments for their business transactions. Based on the results of interviews with Customer Service at Bank Syariah Mandiri, it is said that opening a checking account is very easy. Customers can open a checking account by bringing the requirements set by Bank Syariah Mandiri to the department, Customer Service then the customer can fill out a current account opening form and also fill out a customer approval letter. for banks to manage these funds so that they can be channeled back in the form of profitable financing. After that, customers can make an initial deposit of Rp. 500.000 for individual customers and Rp. 1.000.000 for corporate customers. Current accounts are mostly used for business transactions. Customers can 
withdraw their funds whenever needed. Therefore, current accounts are provided with facilities in the form of checks / bilyet giro, customers can buy checks / bilyet giro for Rp. 100.000. The checking account owner is required to provide sufficient funds in his account to ensure that he can fulfill the responsibility for any withdrawal using a check/bilyet giro. In addition, current account customers are also given other withdrawal facilities, such as via ATM cards or clearing.

Based on the results of interviews with the Branch Operation \& Service Manager at Bank Syariah Mandiri, Palangka Raya Branch, the application of the contract is wadi'ah yad dhamanah used in current account products because current accounts are mostly used for customer business activities so that they rarely settle. With the implementation of the contract wadi'ah yad dhamanah, customers can withdraw funds whenever needed. In addition to fulfilling customer needs in financial transactions, the benefits obtained by the bank by implementing the contract wadi'ah yad dhamanah make it easier for banks to manage the funds entrusted to be channeled back in the form of financing that can generate profits. All profits or losses from channeling funds become the property and responsibility of Bank Syariah Mandiri. For current account customers, Bank Syariah Mandiri can provide Bank Syariah Mandiri with the proceeds from the management of funds to current account customers in the form of monthly bonus in accordance with Bank Syariah Mandiri policies.

The practice of giving bonus to current account products at Bank Syariah Mandiri, Palangka Raya Branch is as follows: first, customers deposit their funds with Bank Syariah Mandiri in demand deposits products, and bank Syariah Mandiri distributes its funds in the form of financing, both with profit sharing, and bank Syariah Mandiri provides bonus to customers from the income it gets from financing current accounts. Second, giving bonus on current accounts completely depends on Bank Syariah Mandiri policies and the amount of bonus giving for current account products is not determined in a certain nominal or 
percentage upfront. The bonus is not agreed upon in the contract and giving bonus on current account products stated earlier on the website Bank Syariah Mandiri, namely "Monthly bonus are given according to Bank Syariah Mandiri policies" is a form of promotion used by Bank Syariah Mandiri to attract people to save their funds in the form of demand deposits and to keep customers loyal to Bank Syariah. Independent. Third, giving a bonus for current accounts in the form of money that is added directly to each customer's account. In addition, bonus can also be given in the form of prizes in the form of office equipment, and also through promotion, namely Giro Prima for customers whose accounts are always active and also have an account balance of more than 100 million, Bank Syariah Mandiri provides free RTGS transfer fees for BSM Giro customers and factors that are considered by Bank Syariah Mandiri in giving bonus are based on the benefits obtained by Bank Syariah Mandiri. If Bank Syariah Mandiri's profit increases, bonus can be given, but bonus cannot also be given if Bank Syariah Mandiri's income has decreased. In addition, bonus are given taking into account the activity of the customer's current account and bank Syariah Mandiri is fully entitled to increase or decrease the percentage of bonus on current accounts.

\section{Islamic economic perspective on the practice of giving bonus in current accounts wadi'ah at Bank Syariah Mandiri Palangka Raya branch.}

The giving of bonus is practiced by Islamic Banks in accordance with the National Sharia Council Fatwa No: 01 / DSN-MUI / IV / 2000 concerning Current Accounts. According to the fatwa, the requirements in current accounts wadi'ah are deposit, can be retrieved at any time, and no compensation is required, except in the form of gift voluntary ('athaya) from the bank. This is in accordance with the practice of giving bonus to current accounts at Bank Syariah Mandiri Palangka Raya Branch. Based on the results of interviews with Customer Service Bank Syariah Mandiri Branch Palangka Raya, current accounts can deposit their funds and can 
withdraw demand deposits at Bank Syariah Mandiri Palangka Raya Branch whenever needed by the customer provided that they bring a check/bilyet giro and the customer's balance is always available when want to withdraw demand deposits. Bonus are given based on the policy of Bank Syariah Mandiri, there are no terms or conditions set by Bank Syariah Mandiri for customers who get a bonus demand deposit at Bank Syariah Mandiri. Bonus are given by the bank if the bank's income has increased, however, if not then the bonus cannot also be given because basically the bank is only a place for customers to deposit their checking funds. Basically, bonus are voluntary from Bank Syariah Mandiri.

In theory, a bonus is a gift given by banks to customers who save their funds in the bank in the form of savings or current accounts wadi'ah (Mubarok, Hasanudin, \& Sanrego, 2013: 341). Prizes are gifts that are nonbinding in nature and aim to make customers loyal to Islamic Banks. Sharia Financial Institutions give prizes to customers in order to attract the public to fundraising products in the form of promotional gifts and prizes for customer savings (Fatwa Dewan Syariah Nasional No.86/DSNMUIXII/2012 Tentang Hadiah Dalam Penghimpunan Dana Lembaga Keuangan Syariah : 8). In theory, one form of promotion used to communicate and introduce products carried out by a company on its marketing targets is information conveyed via the internet, one of the websites (Napitupulu, $2016:$ 180). This is also used by Bank Syariah Mandiri, the media website used by Bank Syariah Mandiri is a form of promotion for Bank Syariah Mandiri in introducing products owned by Bank Syariah Mandiri to the public, one of which is demand deposits. Based on the results of interviews with the Branch Operation \& Service Manager of Bank Syariah Mandiri, Palangka Raya Branch, there is a bonus on the page website Bank Syariah Mandiri current account products at Bank Syariah Mandiri which aims to attract people to save their funds in the form of demand deposits and to keep customers loyal to the Bank. Syariah Mandiri. Giving bonus is basically a form of gratitude from Bank 
Syariah Mandiri to customers for saving their funds in Bank Syariah Mandiri.

According to the Fatwa of the National Sharia Council No.86 / DSNMUI / XII / 2012 regarding the conditions for giving gifts, it is not agreed upon, does not lead to hidden usury, and, should not be a custom ( 'urf). According to economics and finance expert Suherman Rosyidi stated that $u r f^{\prime}$ or the custom which is prohibited by the DSN MUI in the fatwa prize aims to avoid changing the intention of saving or placing funds into wanting to get a prize (Setiawan, Rahmawati, \& Wahidin, $2019: 41$ ). Based on the results of interviews with the Branch Operations \& Service Manager at Bank Syariah Mandiri, for now Bank Syariah Mandiri's income continues to increase so that Bank Syariah Mandiri provides a bonus on current account products at the end of each month to current account customers as stated earlier on the page, website Bank Syariah Mandiri namely "The monthly bonus given is in accordance with Bank Syariah Mandiri policy". In practice, giving bonus to current accounts wadi'ah at the Palangka Raya branch of Bank Syariah Mandiri is in accordance with an Islamic economic perspective, bonus are not agreed upon in the contract. Bonus are given by Bank Syariah Mandiri by taking into account the benefits of Bank Syariah Mandiri every month and bonus are given in accordance with Bank Syariah Mandiri policies, it's just that if bonus are given continuously and become a custom ( 'urf) it is feared that the intention of customers who initially only put funds into want to get a prize so that it is prohibited in the Fatwa DSN MUI because it can lead to covert usury practices, then giving this bonus can be a mistake that should be reviewed by Bank Syariah Mandiri.

\section{CONCLUSION}

Based on the description in the discussion, this research can draw the following conclusions In practice, bonus are not agreed upon in the contract. Bonus are given by Bank Syariah Mandiri by taking into account the benefits of Bank Syariah Mandiri every month so bonus cannot also be 
given if the bank's income has decreased. Bonus are not set based on a certain percentage, and bonus are given based on Bank Syariah Mandiri policies. The bonus are given in the form of money that is added directly to each customer's account, apart from in the form of additional money, the bonus that are given also come in the form of prizes such as office equipment, and also through the promotion Giro Prima which is for customers who are active and have more account balances. from 100 million, you will get free transfer fees via RTGS for the current account.

The practice of giving bonus to current accounts wadi'ah at the Palangka Raya branch of Bank Syariah Mandiri is in accordance with an Islamic economic perspective. The bonus is not agreed upon in the contract. Bonus are given by Bank Syariah Mandiri taking into account the benefits of Bank Syariah Mandiri every month. The statement of giving bonus through the page website Bank Syariah Mandiri is a form of promotion used by Bank Syariah Mandiri that can be justified, it's just that if bonus are part of the requirements that can lead to the practice of hidden usury and will become the norm (habit 'urf) because it continues continuously done, the giving of the bonus can be an error which should be reviewed by Bank Syariah Mandiri.

\section{REFERENCES}

Arifin, Z. (2006). Dasar-dasar manajemen bank syariah. Jakarta, Indonesia: Azkia.

Al Hadi, Abu Azam, (2017). Fikih Muamalah Kontemporer, Depok: PT RajaGrafindo Persada

Ascarya, (2008). Akad dan Produk Bank Syariah, Jakarta : PT. RajaGrafindo Persada, cet1.

Bungin, Burhan (2003). Analisis data Penelitian Kualitatif, Jakarta: PT RajaGRafindo Persada.

Darsono, \& Antonio, M. S. (2017). Dinamika produk dan akad keuangan syariah di Indonesia (Cetakan ke-1). Depok: Rajawali Press.

Fatwa Dewan Syariah Nasional No.86/DSN-MUIXII/2012 Tentang Hadiah Dalam Penghimpunan Dana Lembaga Keuangan Syariah.

Fauzia, Ika Yunia (2014). Prinsip Dasar Ekonomi Islam: Perspektif Maqashid Al- Syariah, Jakarta: Kencana,

Fitria, T. N. (2016). Kontribusi Ekonomi Islam Dalam Pembangunan Ekonomi Nasional. Jurnal Ilmiah Ekonomi Islam, Vol. 2, No.3 
Hakim, A. A. (2011). Fiqih perbankan syariah: Transformasi fiqih muamalah ke dalam peraturan perundang-undangan (Cet. 1). Bandung: Refika Aditama.

Hasan, N. I. (2014). Perbankan Syariah. Jakarta: Referensi (GP Press Group).

Haykal, Nurul Huda Mohammad, (2010). .Lembaga Keuangan Islam, Jakarta: Pernada Media Group.

Ikit, (2018).Manajemen Dana Bank Syariah, Yogyakarta: Gava Media Anggota IKAPI DIY.

Kasmir, S. (2002). Dasar-dasar perbankan. Jakarta, Ind.: PT RajaGrafindo Persada.

Mardani, (2018). Hukum Islam dan Hukum Positif Indonesia, Depok: PT RajaGrafindo Persada,

Mubarok, J., Hasanudin, H., \& Sanrego, Y. D. (2016). Fatwa Tentang Hadiah Di Lembaga Keuangan Syariah. MIQOT: Jurnal Ilmu-ilmu Keislaman, Vol.37, No.2.

Muhammad, (2014). Manajemen Dana Bank Syariah, Jakarta:PT Raja Grafindo Persada,

Murdadi, B. (2015). Menguji Kesyariahan Akad Wadiah Pada Produk Bank Syariah. Jurnal: Maksimum, Vol.5, No.1

Napitupulu, R. M. (2016). Kajian Internet Marketing Sebagai Media Pemasaran Pada Industri Perbankan Syariah, Jurnal: AlMasharif, Vol.4, No.2

Rozalinda, (2014). Ekonomi Islam: Teori dan Aplikasinya pada aktivtas ekonomi, Jakarta: PT RajaGrafindo Persada.

Rozalinda, (2016).Fikih Ekonomi Syariah Prinsip dan Implementasinya pada sector Keuangan Syariah, Jakarta: PT RajaGrafindo Persada.

Setiawan, M. R., Rahmawati, R., \& Wahidin, W. (2019). Implementasi Fatwa DSN-MUI NO: 86/ DSN-MUI/ XII/ 2012 Tentang Hadiah Dalam Penghimpunan Dana. BANCO: Jurnal Manajemen dan Perbankan Syariah, Vol.1, No.1

Sugiyono, (2013). Metodologi Penelitian Kuantitatif Kualitatif dan R\&D, Bandung: Alfabeta.

Umam, Khotibul Setiawan Budi Utomo, (2016). Perbankan Syariah: Dasar-dasar dan Dinamika Perkembangan di Indonesia, Jakarta: PT RajaGrafindo Persada,

Yusuf, Muhammad, (2011). Bisnis Syariah Edisi 2, Jakarta: Mitra Wacana Media.

Widayatsari, A. (2013). Akad Wadiah dan Mudharabah dalam Penghimpunan Dana Pihak Ketiga Bank Syariah. Economic: Jurnal Ekonomi dan Hukum Islam, Economic: Jurnal Ekonomi dan Hukum Islam, Vol. 3, No. 1

www.mandirisyariah.co.id. 